\title{
Social Technology as a Sustainable Public Policy:The Mandalla Project in Ceará
}

\author{
Josimar Souza Costa',Anna Beatriz Grangeiro Ribeiro Maia ${ }^{2}$,Ana Rita Pinheiro de Freitas ${ }^{3}$, \\ José Carlos Lázaro da Silva Filho ${ }^{4}$, Mônica Abreu Sá de Abreu ${ }^{5}$, Marcelo Correia Teixeira Filho ${ }^{6}$
}

\begin{abstract}
Environmental degradation in semi-arid Northeast has been a great challenge for the Brazilian government. The need to generate employment and income, justifies the establishment of productive activities competitive and covering the dimensions of sustainability. In this context, there is the movement of Social Technology (ST), aimed at social inclusion and development through the appropriation of simple technologies, inexpensive and consolidated in the culture of the community benefit. As a public policy of the government of Ceará, appeared the Mandalla Project, using irrigated agriculture and agribusiness production system, which includes the creation of small animals from natural methods. This study aims to analyze the ST Mandalla as a public policy that promotes sustainable development. The results show that this technology, contributes significantly to the sustainable development of semi-arid and improving the quality of life of communities served when examined against the dimensions of Sustainable Development model of Sachs (2002).
\end{abstract}

Keywords: mandalla; social technology; social innovation; public policy; sustainable development.

Business Department, Federal University of Ceará.Av. da Universidade, 2470 - Benfica, Zip Code 60020-180. Fortaleza-Ceará-Brazil Phone: 55-85-33667825, 55-85-88278255. E-mail: 'josimarscosta@gmail.com, ${ }^{2}$ biagrm@alu.ufc.br, ${ }^{3}$ anarital802@hotmail.com, ${ }^{4}$ lazaro@ufc.br, ${ }^{5} \mathrm{mabreu@ufc.br,}{ }^{6} \mathrm{marcelo-maac@hotmail.com}$ 


\section{Introduction}

Environmental degradation in semi-arid northeast is a permanent challenge for the Brazilian government. Public policies should guide actions aimed at rationalizing land use and natural resources, increase agricultural productivity without compromising the productive potential of semiarid lands and ensure environmental sustainability.

Ceará is within this context, with a $148,825.6 \mathrm{~km}^{2}$ territory, corresponding to $9.6 \%$ of the area of the Northeast Region and $1.75 \%$ of Brazilian territory. The territory of Ceará is limited to the north with the Atlantic Ocean, to the south with Pernambuco, to the east with Rio Grande do Norte and Paraiba and with Piaui to the west. Within these limits, $86.8 \%$ of its area is nestled in the semi-arid, according to the official definition by the Ministry of National Integration in 2005. The warm tropical climate is predominantly semiarid and is characterized by irregular distribution of rainfall in space and time, which leads to shortage of water for the population. The soils are fertile, being the caatinga the broader vegetation, present in $69.2 \%$ of the total area of the state. In addition to an extensive coastline, it has mountain regions, with peaks exceeding I,000 meters of altitude. Since 2009 , is composed by 184 municipalities, with its capital Fortaleza (IPECE, 2009).

The story of misery and hunger in Ceará is the epitome of reality in the Northeast with all the nuances of the challenges faced by his people, impacting federal investments for the construction of huge dams for water control, fleets of planes for cloud seeding precipitation forcing, food distribution programs and, currently in operation, a sophisticated climate prediction system (Nelson \& Finan, 2009). In the past, the way to escaping this suffering situation was evidenced by the migration of rural workers in search of better social conditions in capital and major urban centers, which usually did not come to fruition (Silva, Sampaio, \& Alencar, 2009).

The resilience of these people facing his geographical vulnerability, associated with cyclical droughts, due to rainfall poorly distributed spatially and temporally, demonstrates its high social capital. Conceptually, social capital is related to a public good characteristics that favor the organization's informal social networks overlap, increasing the level of cooperation between the actors and their effectiveness (Granovetter, 1985; Coleman, 1998; Fukuyama, 1995; Putnam, 2000). In this context of social injustice and geographical self-image of the suffering of the backcountry of northeastern carves a strong culture. The authenticity, perseverance, joy and great strength of this people are rooted in its crystallized religious belief, expressed by the courage and his outlaw country music (Greenfield, 2009).
The challenges are even greater for the population of Ceará, taking into account the scarcity of economic resources caused by the high temperatures characteristic of the climate and shallow soils, which makes agricultural production a difficult task. In this context, the need to generate employment and income justifies the establishment of productive activities competitive, environmentally sustainable, and covering the dimensions of social, cultural, territorial, economic and political (Gariglio, 20 I0; Sachs, 2004).

Thus, the implementation of public policies that promote the sustainability of this biome plays a crucial role. Social Technology (ST) emerges as a viable alternative motion with its inherent simplicity, low cost and consolidated in the culture of its users. The result of these technologies has a positive social impact, and has reached maturity and credibility to attract the interest of public managers, despite their low visibility in society, given their local and their applicability toward individuals, families, cooperatives and associations (Lassance Jr, 2004; Rodrigues \& Barbieri, 2008; Maciel \& Fernandes, 20I I).

In this sense, appeared in 2007, as a public policy of the government of Ceará, Mandalla Project, which uses a system of irrigated agricultural production and agribusiness, including the creation of small animals from natural methods. The project has the primary function of generating social change from the democratization of knowledge and fostering the development of sustainable enterprises, "enabling the production and educating responsible for conscious consumption" (DHSA, 2008).

Thus, this study aims to analyze the TS Mandalla as a public policy that promotes sustainable development (SD). To reach that goal, the article is organized as follows: in the second topic, we present some discussions about the concept of public policies for the SD and its dimensions. The third topic, it is a reading of the theoretical approaches that talk about social innovation, specifically the ST Mandalla, and the fourth comprises the methodological procedures used to achieve the study that led to this article. The fifth chapter covers analysis of the results, while the latter presents final considerations and presents suggestions for future research. Sustainable Public Policies

Public policies are understood here as the "State action", considering the difference between State and Government, in which state is the set of permanent institutions (state agencies) and government is the set of programs and projects (assume and perform the functions of State during a given period) (Höfling, 200I). That is, public policy is the state implementing a project of the government, through programs and actions aimed at specific sectors of society. 
Of the various definitions and models of public policy, one can extract and summarize major elements: public policy allows to distinguish between what the government intends to do and what it actually makes it involves various actors and levels of decision, even if materialized through governments, and not necessarily restricted to formal participants, since the informal are also important: it is comprehensive and not limited to laws and rules, is an intentional action, with goals to be achieved, and while managing impacts on short term, has a long duration (Souza, 2006).

In the United States, this line of research in political science began to be instituted in the first years of the 1950s under the label "science policy". In turn, in Europe, particularly Germany, the concern with certain policy fields only takes strength in the early 1970s when, due to the rise of social democracy, planning and sectoral policies have been significantly extended (Frey, 2000). Meanwhile, in Europe the area of public policy emerges as an outgrowth of studies based on theories that explain the role of the state and one of its most important institutions - the government - producer par excellence of public policies. In the U.S., by contrast, the area appears in the academic world without establishing relations with the theoretical underpinnings of the role of the state, passing directly to the emphasis on studies of government action (Souza, 2006).

It is considered that the area of public policy had big four "fathers" founders: Harold Laswell (1936), Herbert Simon (1957), C. Lindblom (1959) and D. Easton (1965) (Souza, 2006). Laswell introducing "policy analysis" and describes the public policies in the context of bureaucracy, as devices seeking to promote a specific process and contain the rapid passage of the stimulus of government in action, while Simon reveals the extent of control the organization through public policies (Brickman \& Eller, 2006). Lindblom questioned the emphasis on rationalism and Laswell and Simon proposed the incorporation of other variables to the formulation and analysis of public policy, how relations of power and integration of different phases of decision making, which does not necessarily have an end or a beginning. Easton, however, contributed to the area to define public policy as a system, i.e., a relationship between design, results and the environment (Souza, 2006).

In Brazil, studies on public policies emphasized the analysis of structures and institutions and the characterization of negotiation of specific sectoral policies, and have only recently been made (Frey, 2000). During the consolidation of modernizing the state apparatus and politics from the Revolution of 1930, fed a great debate about the expansion of agriculture and national integration as a development policy (Gehlen, 2004). Thus, it is understood that public policies were then directed to stimulate the productive labor of goods and ensure productivity. According to Gehlen (2004), progress or rural development meant to replace the wild (fauna and flora) and native (indigenous peoples and shifting cultivators) by culturalized and the market.

Especially in the agricultural, public policies for small farmers in Brazil, including the National Programme of Family Agriculture (Pronaf), resulted from demands and pressures of their organizations and representations of class and social struggles for many years. The design and implementation of Pronaf include the participation of farmers' organizations. These changes express a new vision of the meaning and role of family farming in Brazil, especially for the SD (Gehlen, 2004).

Family farms, chosen as the key player of the policy to rural development, despite all the predicaments of public action, it is nonetheless indicative of changes in the government orientation (at least in discourse) in relation to agriculture and farmers themselves. Even more when you want to extend the concept of development with the notion of sustainability incorporating other spheres of society - beyond the strictly economic - such as education, health and environmental protection (Carneiro, 1997).

In Brazil, the concept of local development is strengthened through public policies and local formal and informal organizations. Gehlen (2004) reveals a strategy that has been taken to circumvent social exclusion in rural areas. It is the incorporation of low-cost technological resources through membership and community actions that optimize profits by buying and selling common pressure to bargain for better prices or condominium building systems of collection and transportation and in some cases, manufacturing of products. This strategy, however, will succeed only if it is anchored in public policies to support financial and technical, professional qualifications and infrastructure (Gehlen, 2004) Thus, in search of the SD, the "State action" makes use of current technologies and policies to provide people with the necessary infrastructure. The SD is defined as development that "meets present needs without compromising the ability of future generations to meet their own needs" (WCED, 1987, p. 43). On this topic and academic discussions and policies for its range of application and operational viability of the national and international, Munasighe (2002) says that each passing day the decision makers are more concerned with finding solutions to problems critical in terms of economic, social, political and environmental.

The SD concept and its practical operation have not yet found consensus in the scientific community (Mebratu, 1998). However, it is considered that any new development should not only align with at least three analytical dimensions (economic, social and environmental) interdependent, 
but also the knowledge and forms of alternative assessment (Munasinghe, 2002). From this perspective, Milanez (2004) adds a cultural dimension, in order to address a local view rather than universal solution.

Sachs (2002) attaches great importance to the social dimension at the time to understand that development is designed to solve society's problems. Then added to the four dimensions already mentioned, four other: territorial, ecological and political (in turn broken down into national and international). Figure I shows the dimensions according to Sachs (2002), describing its main features.

In line with Maurer, Marquesan and Silva (20I0), the social, environmental and economic model in a triple bottom line are the most highly regarded among academics and managers because of the ease of understanding when compared to the eight dimensions of Sachs (2002). In this study, the eight dimensions allow you to observe the phenomenon of state action (policy) from the perspective of the SD, taking into account the social innovations. In response, the next topic discusses the theoretical and conceptual construction of ST, reflected in the Project Mandalla.

\section{Social Innovation}

An innovation can be defined as a range of different relationships between actors, processes, objects and systems, disparate complexities also that, from a rearrangement of its elements generates differentiation, ie, new socio-organizational functions (Rollin \& Vicent, 2007). Specifically to treat social innovation, we take the concept of the Centre de recherche sur les innovations sociales (Crises), Canada, which relates to the possibility of social transformation of individuals, dividing it into three different levels of analysis: social innovations on the employment relationship and employment generation; social innovations in living conditions, territorial and social innovations (CRISES, 2004). As a focus of action, we highlight the poor or the lower layer of the social pyramid.

The base of the pyramid, the layer composed of the world population with per capita income up to $\$ 2.00$ per day, you need alternative sustainable development (Prahalad, 20I0). An alternative to the development of this segment of the population may be the adoption of public policies that use social innovations suited technologies to promote economic, social and environmental sustainability. According to Rutkowski (2005), the issue of sustainability and its interrelation with the construction of knowledge evoke a discussion of the scientific, technology, innovation and social demands.

\begin{tabular}{|l|l|}
\hline Social & $\begin{array}{l}\text { - Social homogeneity in a reasonable level } \\
\text { - Income distributed fairly } \\
\text { - Decent quality of life and work full and / or autonomous } \\
\text { - Access to resources and social services equally }\end{array}$ \\
\hline Cultural & $\begin{array}{l}\text { - Innovation and respect for tradition in balance } \\
\text { - Autonomy for the elaboration of a national integrated and endogenous without } \\
\text { invasion } \\
\text { - Confidence considering the external environment }\end{array}$ \\
\hline Ecological & $\begin{array}{l}\text { - Preservation of the potential of capital nature in its production of renewable } \\
\text { resources } \\
\text { - Limit the use of non-renewable resources }\end{array}$ \\
\hline Environmental & - Respect for self-purification capacity of natural ecosystems \\
\hline Territorial & $\begin{array}{l}\text { - Public investment balanced between urban and rural } \\
\text { - Improving the urban environment } \\
\text { - Addressing the inter-regional disparities } \\
\text { - Biodiversity Conservation (ecodevelopment) }\end{array}$ \\
\hline Economic & $\begin{array}{l}\text { - Balancing intersectoral economic development } \\
\text { - Food safety }\end{array}$ \\
\hline $\begin{array}{l}\text { Political (National and } \\
\text { International) }\end{array}$ & $\begin{array}{l}\text { - Democracy for universal human rights } \\
\text { - Partnership between the State and entrepreneurs to implement the national } \\
\text { project } \\
\text { - Reasonable level of social cohesion } \\
\text { - Co-development of the hemispheres, based on the principle of equality }\end{array}$ \\
\hline
\end{tabular}

Figure I - Dimensions of sustainable development. Source:Adapted from Sachs (2002)

ISSN: 07 I8-2724. (http://www.jotmi.org)

Journal of Technology Management \& Innovation (c) Universidad Alberto Hurtado, Facultad de Economía y Negocios. 
In the model of linear chain of conventional technological innovation, social development results from economic development generated by the technology, sometimes resulting from technological research originated from scientific research.The model assumes that science is constantly seeking the truth, and the technology evolves linearly searching efficiency. Thus, the stage of development of societies is directly proportional to its level of technological advancement. However, society as a whole, the economic interests and political influence that permeate the core technology and its outcome. In such a way, it can be said that technologies are socially constructed (Rutkowski, 2005).

At the World Business Council for Sustainable Development, WBCSD (2002), a coalition of 160 international companies by SD, innovative technologies, however, are discovered, developed and negotiated in an environment that consists not only of markets, supply chains and distribution networks but also a number of concerns and social systems of support, a growing gap between rich and poor, lack of access to real knowledge, even in a sea of data and growing concerns about the effects of globalization.

\section{Social Technology and Project Mandalla}

In less developed countries from the 1960s, the unemployment rate and underemployment was already a serious problem to be solved. The persistence of this condition raised questions about the choice of technologies "appropriate" to be adopted, seeking to solve it (Grieve, 2004). Discussions and research on these technologies appropriate within wider considerations than by the general perspective of the capital, were developed in the 1960s and 1970s, such as alternative technologies in use in developed countries, and transplanted to the other, mainly through multinational companies (Rodrigues \& Barbieri, 2008).

From the 1980s, the face of globalization, with the consequent intensification of competitiveness, leading to social exclusion and environmental degradation, ascended this technology under the name of social technology, with broad support from agencies of the United Nations, governments and part of civil society.

The Institute of Social Technology sets the ST as a set of "techniques, processing methods, developed and / or implemented by the interaction with the public and appropriate for it, that represent solutions to social inclusion and improving living conditions." From this perspective, the central argument of ST is that technology is socially constructed as "relevant social groups" under the "seamless fabric" of society (Dagnino, Brandão, \& Novaes, 2004), ie, without division of interests between the actors involved, the ST has to be developed with the function of promoting inclusion not only social but also economic, social and environmental area. In 2005, several civil society organizations, government institutions, companies, universities and research institutes began to discuss alternatives to solve major country problems and the consequent successful experiences, which were still restricted to certain locations. The Social Technology Network (RTS, 20I I) was formalized in April I4, 2005, in Brasilia, so articulate and organized, the result of several months of discussions and lots of participation.

The RTS aims to expand the dissemination and replication of social technologies, enabling social inclusion, employment and income generation and promotion of sustainable local development. The RTS supports activities that encour-

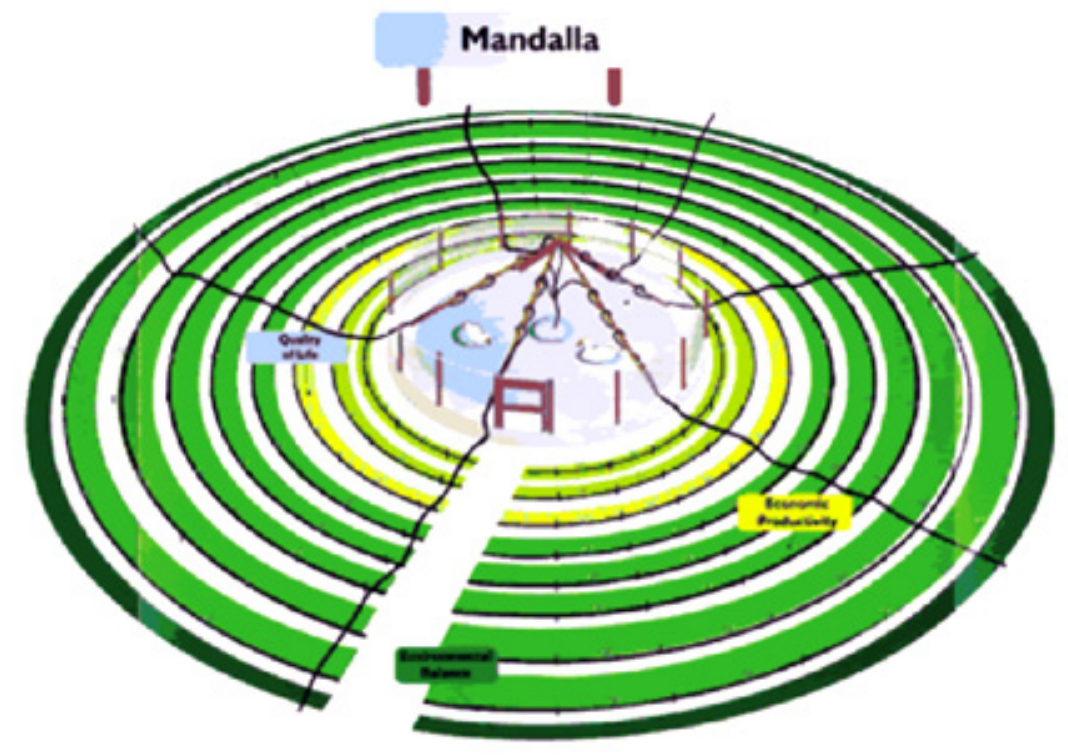

Figure 2 - Mandalla Project. Source: Labad and Rodrigues (2006, p. 179).

ISSN: 07 I 8-2724. (http://www.jotmi.org)

Journal of Technology Management \& Innovation (c) Universidad Alberto Hurtado, Facultad de Economía y Negocios. 
age interaction between local communities and promote solutions to people's lives. Institutions that are part of the RTS, so far, have one common purpose: to understand social technologies as important tools for human development and the formation of a more just society (RTS, 20II; Maciel \& Fernandes, 20I I).

Among several examples of action of RTS, it is worth mentioning that "in Ceara, a technique helps producers make better use of soil. It is the Mandalla, and with it, the clever use of water reduces the impacts of drought (RTS). As part of an emerging architecture, supported by information technology and the implementation of a simplified TS feasible and low operating cost in the area of creativity makes the impossible possible every day, without borders is a challenge to lose sight, emerging from this idea-DHSA Mandalla Project (Labad \& Rodrigues, 2006).

In general, the primary function of Mandalla is to generate social change from the democratization of knowledge and fostering the development of sustainable enterprises, "enabling the production and educating responsible for conscious consumption" (DHSA, 2008).

According Messiano and Dias (2008), the Mandalla production project is a ST that uses simple technology and low cost, value the traditions and customs, is deployed on small farms, produce organic foods, with the intention of meeting the need of farmers related to agricultural inputs and pesticides, and aims to improve the quality of life of the families involved, generating income through the sale of the surplus in the local market. It thus provides the social, economic and environmental, because it uses only natural resources, besides being reapply.

For the Agency Mandalla (DHSA, 20I I), the Mandalla represents a system that provides an environment for economic restructuring and promotion and facilitation of a strategic simplified tooling, culminating in rational reuse of waste of human natural site.

Mandalla size varies according to the available area. If there is availability of space, Mandalla can take up to I / 4 of a hectare, or even smaller in size, to be deployed in the backyards of the houses of farmers. In every area of 2,500 square meters ( I / 4 ha) irrigated by submersible pump, are grown up to 64 types of crop plants, 10 species of animals and diverse fruit trees up to 450 (DHSA, 20I I).

It is perfectly possible for a rural family to live a in an area of just over 2 hectares $\left(20,000 \mathrm{~m}^{2}\right)$, drawing from it its natural power base, and still get somewhere around US $\$ 2,500.00$ per month, with the sale of surplus so associative. And all this from an area of 2,500 $\mathrm{m}^{2}$ (Labad \& Rodrigues, 2006).
Thus, to prevent migration of the countryside to the outskirts of urban centers and to promote self-reliance of families, TS Mandalla production contributes to the good performance and the strengthening of family farming (Messiano \& Dias, 2008; DHSA, 20I I).

\section{Methodology}

Martins and Theóphilo (2007, p. 37) teaches that "science seeks to capture the reality, the methodology addresses how this can be achieved." In this context, the design methodology of scientific research was outlined in the midst of addressing the problem described above, the procedures for collecting and analyzing data.

The nature, it is a qualitative research, an analysis of building aspects of the phenomenon, identifying the essential characteristics of Mandalla Project of the Government of the State of Ceará, while TS adopted as public policy development.

As to the objectives, the research is classified as descriptive as it aims to analyze the Project Mandalla State Government of Ceará, while TS adopted as public policy development. Gil (1999, p. 70) notes that "descriptive research has as main objective to describe characteristics of a given population or phenomenon or establishment of relations between the variables."

The study adopts the following methodology: literature research, providing theoretical background on the issues Mandalla social technology and design, sustainable public policies; desk and field research, in which data and information are collected from the Mandalla Project of the Government of the State of Ceará; still using interviews and content analysis. After the identification of references, which allowed to build on the theoretical and TS Project Mandalla and sustainable public policy, there was a case study of the Mandalla Project from the State Government of Ceará. The sources of evidence used in the research include the set of documents, files, reports, participant observation and interviews with members of the project in 2008 and 2009.

According to Yin (200I, p. 9I), "the evidence for a case study can come from six different sources: documents, archival records, interviews, direct observation, participant observation and physical artifacts." In this study, we used all possible sources of evidence.

Besides the techniques already presented, this study used content analysis of documents and interviews Mandalla Project of the Government of the State of Ceará, in order to gain a greater understanding of the research object. Freitas and Janissek (2000) state that content analysis "is an indirect method of observation, as it is written or verbal expression 
of the respondent will be observed." Richardson (2008, p. 224) believes that "by its scientific nature, content analysis must be rigorous and precise," based on relevant theories, which should serve as a framework of explanation for the findings of the researcher.

We survey information for 2008 and 2009. Thus, the survey gathered Mandalla 163 projects, including 489 producers. 20 projects were excluded, given the absence of their visit reports, resulting in 143 projects analyzed.

When interpreting the data collected, we used content analysis of reports and videos of Project Mandalla State Government of Ceará, interviews with project participants and interviews with the project coordinator.

The collected data were analyzed in the light of theoretical choice made based on the literature review: the dimensions of the SD Sachs (2002), in order to operationalize the concept of sustainable public policy.

\section{Research Results}

Licensing Project Mandalla of the State Government of Ceará occurred from the visit to the Mandalla Agency's technical coordinator in Paraíba. The partnership took place with support from the creator of the process, Willy Pessoa, responsible for transfer of technology and technical training of would-be replicators for family farmers. This action highlights the licensing of the technology dimension of national policy for sustainable development as outlined in this theoretical study, when the state identifies the partnership with developers to implement a national project (Sachs, 2002).

The project was implemented by the Department of Agrarian Development of Ceara and disseminated throughout the state. According to the state coordinator of Project Mandalla, Farias Jr., this work began in 2007, and his first Mandalla were implemented the following year. For him, Mandalla Project was initially conceived in order to meet the demands of family farmers, regarding the needs of food quality and quantity, and also generating employment of family labor, with the consequent generation of income to trade also of surplus production. Clearly, the social, economic and territorial Sachs (2002) permeate the construction of public policy. Farmers are selected from the visit to the site's technical coordinator, who interview the applicants and families and analyzes the area where Mandalla will be installed. It is the desire to engage the family and especially their cultural links with agriculture. The agreement is then made for the group transferring the amount of approximately US $\$ 2,150.00$ for the deployment of the system. The cultural dimension is evident when one observes that the criteria for selection include respect for the tradition of families, while it includes innovation (Sachs, 2002, 2004).
An important feature of the process is the repayment of the loan to the association, in 24 installments, from the eighth month of actual production system. Completed reimbursement, the three farmers can reinvest that money for expansion of the project, and then allow another group to be formed by applying a new Mandalla.The economic and social dimension stands out in this context, given that this transfer of resources enables an expansion of the undertaking by the farmer family or social homogenization, give rise to the extent of benefit to new families.

The requirements for selection of families are segmented into four points, highlighted below:

- $\quad$ To be a family farmer;

- To participate in a community association to be established and defaulting with all legal obligations;

- $\quad$ to form a group of at least three farmers;

- $\quad$ to require, by letter addressed to the Secretary of Agrarian Reform, the establishment of the agreement, stating the location where the project will be developed, a water supply and technical assistance guaranteed by the Company for Technical Assistance and Rural Extension of Ceará (Ematerce) or other competent institution.

Selected groups participate in a structured training in two modules: the first enables them to build adequate infrastructure through a constructivist methodology, "do what he knows," and transfers the second planting techniques and management of Mandalla based on agroecological processes. This training identifies the cultural aspect of respecting the traditions and enables the inclusion of new techniques. At the same time, presents the characteristics of the ecological, environmental and territorial.

In the analysis of projects implemented in two years Mandalla selected for this study, 2008 and 2009, there was a drop in the implementation of projects, Mandalla 100 in 2008 to 68 in 2009 . However, it is noteworthy that the largest amount given in the first year of installation is due to backlogs in the year 2007.

In 100 Mandalla implemented in 2008 , benefited 300 farmers in 20 counties, as provided in the 2007-2010 Report: Caridade and Paramoti (Macroregion Caninde Rally - 14 Mandalla) Viçosa do Ceará and Tianguá (Macroregion Chapada Ibiapaba - II Mandalla); Irapuan Pinheiro and Piquet Carneiro (Macroregion Central Hinterland - 8 Mandalla); Acopiara and Umari (Macroregion Central South Hinterland - 7 Mandalla); Quiterianópolis (Macroregion of Inhamuns Rally - 13 Mandalla), Araripe, Barbalha, Jardim, Mauriti, Milagres , Porteiras and Salitre (Macroregion Cariri - 27 Mandalla) Tururu and General Sampaio (Macroregion Valley Curu I Aracatiaçu - 8 Mandalla) and Ocara and Baturité (Macroregion Massif Baturité - 12 Mandalla). These municipalities

ISSN: 07 I8-2724. (http://www.jotmi.org)

Journal of Technology Management \& Innovation (c) Universidad Alberto Hurtado, Facultad de Economía y Negocios. 
Mandalla awarded the project in 2008, received from the state government of Ceará investments in materials, tools and training to US $\$ 140,160.00$, which gives an average of US $\$ 467.20$ per beneficiary family.

In 63 Mandalla established in 2009, benefited 189 farmers in 20 counties, as provided in the 2007-2010 Report: Pacajus (Macroregion Fortaleza Metropolitan - 4 Mandalla) and Canindé Madalena (the Canindé Macroregion Rally - 13 Mandalla) Viçosa do Ceará , Croatá and Ibiapina (Macroregion Chapada Ibiapaba - 10 Mandalla); Jaguaretama and Morada Nova (Macroregion Jaguaribe - 12 Mandalla) Senator Pompeu, Milhã and Solonópole (Macroregion Central Hinterland - 9 Mandalla), Lavras da Mangabeira, Saboeiro, Carius and Iguatu (Macroregion Central South Hinterland - II Mandalla) and Tamboril (Macroregion Rally of Inhamuns - 5 Mandalla). These municipalities awarded the Mandalla project in 2009, received from the state government of Ceará investments in materials, tools and training, totaling US $\$ 126,302.00$, which gives an average of US $\$ 668,76$ per beneficiary family.

The Mandalla have the primary function of food production to ensure household food security and, with the surplus to generate income. The sample showed that $19.6 \%$ of projects achieved at least the level of subsistence production, ensuring the improvement of household food quality. The sale of the surplus of $69.6 \%$ of families resulted in a mean increase of US $\$ 176.50$ per family. Only $8.7 \%$ had discontinued their projects, and $2.1 \%$ were still being implemented. Excluding, however, still non-productive projects, all of the other improved household food quality, resulting in indirect income as it saves buying food in the diet. These results demonstrate the economic and social development.

The management of Mandalla does not use pesticides, and agro-ecological principles underlying its design. By espousing the work within their own business, the family takes possession of knowledge and techniques, highlighting the social dimension in relation to work full and autonomous, with ample free time.The residues of agricultural feed the animals of creation, and these in turn are used as organic fertilizer.

These results align with the ST public policy development, considering that it was created for the purpose of generating products, while generating economic results and contributes to social change (Capra, 200I).

In interviews, $78.8 \%$ of families said they were satisfied or very satisfied with their projects, $14.4 \%$ said they were somewhat satisfied, and $6.8 \%$ expressed dissatisfied, when considered in the design activity.

The organization of work of these families, as evidenced by the analysis of the testimonies of farmers participating in the project, explains the high level of satisfaction, given that the Mandalla work consists of socially and culturally relevant activities for which they are technically prepared: the creation of animals such as chickens, ducks and fish, planting vegetables, fruits, corn and beans, and preparation and soil management. In such cases, the insertion of new technologies such as irrigation and agro-ecology, from the training and capabilities offered during deployment, ensure the production scale inherent principles of ST (Lassance Jr \& Pedreira, 2004). In short, this feature of the project encompasses all dimensions of sustainability defined by Sachs (2002), except politics internationally.

\section{Final Considerations}

In order to analyze the TS Mandalla as a public policy that promotes the DS in the interior of Ceará, we used bibliographic and documentary research, discussing concepts concerning TS adopted under the dimensions of the DS, and there was a case study investigating information about the project Mandalla production through Mandalla project, the Government of the State of Ceará.

Data analysis and information Mandalla Project, for 2008 and 2009, revealed some characteristics of public policies implemented by this type of TS, especially the high level of continuity, given that $91.3 \%$ of projects implemented in 2008 still in operation, generating jobs and income.

Moreover, the results show that the implanted Mandalla provided many contributions to family farmers and society, such as:

- improving food quality for the families;

- increasing family income;

- improvement of production techniques;

- training of farmers;

- High sense of belonging or integration of farmers;

- appropriate technology to the needs and culture;

- training of team spirit;

- commitment to the enterprise;

- presence of innovation;

- knowledge and performance of the entire production process by farmers;

- environmental responsibility;

- objectives of the community considered.

We conclude therefore that the implementation of social innovations, such as this TS, allows the public administrator to analyze public policies based on criteria of DS. Thus, facilitating the planning and introduction of these actions, so that, as evidenced in this study, as the dimensions of the DS are reached, increases the degree of user satisfaction. 
The analysis of social entrepreneurship investments by the state is multidimensional, and when using the DS model, such as Sachs (2002), is the objectification of the subjectivity inherent in this issue, allowing the public manager to take sustainable decisions.

Considering the importance of TS as a public development policy, it is suggested to broaden your search with other projects Mandalla with a view to a comparison with the results presented in this study, or even to carry out further research on other types of TS.

\section{References}

BRICKMAN, D., Eller, W. S. (2006). A tale of two values: the conflict of equity and efficiency in New York's administrative law tribunal process. Retrieved May 29, 20II, from https://www.sbu.edu/uploadedFiles/Academics/Undergraduate_Programs/School_of_Arts_and_Science/Social_Sciences/Political_Science/Faculty_Pages/Brickman_Danette/ Midwest\%202006.pdf

CAPRA, F. (200I).A Teia da Vida. São Paulo: Cultrix.

CARNEIRO, M. J. (April, 1997). Política pública e agricultura familiar: uma leitura do Pronaf (Public Policy and Family Farming. Estudos Sociedade e Agricultura, 8.

COLEMAN, J. S. (1998). Social capital in the creation of human capital.American Journal of Sociology, 94 (supplement), pp. 95- 120.

CRISES. (2004).An introduction to Crises. Montréal: Université du Québec au Montréal.

DAGNINO, R., Brandão, F. C., \& Novaes, H.T. (2004). Sobre o marco analítico-conceitual da tecnologia social. In: LAS

SANCE JR.,A. E. Tecnologia social: uma estratégia para o de senvolvimento (Pp. 18-64). Rio de Janeiro: Fundação Banco do Brasil.

DHSA. (2008). Perguntas frequentes. Retrieved May II, 20 I I, from http://www.agenciamandalla.org.br

FREITAS, H. M., Janissek, R. (2000). Análise léxica e análise de conteúdo: técnicas complementares, sequenciais e recorrentes para exploração de dados qualitativos. Porto Alegre: Sagra Luzzato.

FREY, K. (2000). Políticas públicas: um debate conceitual e reflexões referentes à prática da análise de políticas públicas no Brasil. Planejamento e Políticas Públicas, 21.

FUKUYAMA, F. (1995). Social capital and the global economy. Foreign Affairs, 74(5), pp. 89-99.

GARIGLIO, M.A. (20 I0). Uso sustentável e conservação dos recursos naturais da caatinga. Brasília: Serviço Florestal Brasileiro.

GEHLEN, I. (Apr/Jun, 2004). Políticas públicas e desenvolvimento social rural. São Paulo em Perspectiva, I8(2).

GIL,A. C. (I 999). Métodos e técnicas de pesquisa social. São Paulo:Atlas.

ISSN: 07 I8-2724. (http://www.jotmi.org) 
GOVERNO Do Estado Ceará. (20I0). Estado libera R\$ 4,5 milhões para municípios do Cariri. Retrieved May II, 20 I , from http://www.ceara.gov.br/salade-imprensa/noticias/884estado-libera-r-45-milhoes-para-municipios-do-cariri

GRANOVETTER, M. S. (1985). Economic action and social structure: the problem of embeddedness. American Journal of Sociology, 9 I (3), pp. 48I-5 I0.

GREENFIELD, G. (2009). Lampião, Luiz and Padim Ciço: Three icons of the Brazilian Northeast. Memory Studies, 2(3), pp. 393-410.

GRIEVE, R. H. (2004).Appropriate technology in a globalizing world. International Journal of Technology Management and Sustainable Development, 3(3), pp. 173-187.

HÖFLING, E. D. (Nov, 200I). Estado e políticas (públicas) sociais. Cadernos Cedes, 2 I (55).

IBGE. (2006). Censo agropecuário 2006. Rio de Janeiro.

IPECE. (2009). Ceará em números. Fortaleza: Instituto de Pesquisa e Estratégia Econômica do Ceará (IPECE).

KIRA, M., Eijnatten, F. M. (2008). Socially sustainable work organizations: a chaordic systems approach. Systems Research and Behavioral Science, 25(6), pp. 743-756.

LABAD, F., Rodrigues, N. (2006). Círculos de prosperidade Projeto Mandalla. In: Küster, A., Martí, J. F. \& Melchers, I. Tecnologias apropriadas para terras secas: manejo sustentável de recursos naturais em regiões semiáridas no nordeste do Brasil. Fortaleza: Fundação Konrad Adenauer.

LASSANCE JR, Pedreira, J. (2004). Tecnologias sociais e políticas públicas. In: FBB, Tecnologia social: uma estratégia para o desenvolvimento. Rio de Janeiro: Fundação Banco do Brasil.

LASSANCEJR, A. E. (2004). Tecnologia social: uma estratégia para o desenvolvimento. Rio de Janeiro: Fundação Banco do Brasil.

MACIEL,A. L., Fernandes, R. M. (Jan/Mar, 20I I).Tecnologias sociais: interface com as políticas públicas e o serviço social. Serviço Social \& Sociedade( I05), pp. I46-I65.

MARTINS, G. D., Theóphilo, C. R. (2007). Metodologia de investigação científica para ciências sociais aplicadas. São Paulo:Atlas.
MAURER, A. M., Marquesan, F. F., Silva, T. N. (2010). As relações entre as inovações sociais e o desenvolvimento sustentável: o caso Univens. Encontro da Associação Nacional de Pós-Graduação e Pesquisa em Administração. Rio de Janeiro:ANPAD.

MEBRATU, D. (1998). Sustainability and sustainable development: historical and conceptual review. Environ Impact Asses Review(18), pp. 493-520.

MESSIANO, Â., Dias, R. (2008). A tecnologia social como estratégia para o desenvolvimento sustentável: o caso da Mandalla. Jornadas Latino-Americanas de Estudos Sociais das Ciências e das Tecnologias - ESOCITE. Rio de Janeiro.

MILANEZ, F. (2004). Desenvolvimento sustentável. In: CATTANI, A. D. A outra economia. Porto Alegre:Veraz.

MUNASINGHE, M. (2002). The sustainomics trans-disciplinary meta-framework for making development more sustainable: applications to energy issues. International Journal of Sustainable Development, 5(I-2), Pp. I26-I84.

NELSON, D. R., Finan,T.J. (2009). Praying for drought: persistent vulnerability and the politics of patronage in Ceará, Northeast Brazil. American Anthropologist, I I I(3), pp. 302316.

PRAHALAD, C. K. (20I0). A riqueza na base da pirâmide: erradicando a pobreza com o lucro. Ed. esp. ver. atual. Porto Alegre: Bookman.

PUTNAM, R. D. (2000). Comunidade e democracia: a experiência da Itália moderna. Rio de Janeiro: FGV.

RICHARDSON, R. J. (2008). Pesquisa social: métodos e técnicas. São Paulo:Atlas.

RODRIGUES, I., Barbieri,J.C.(Nov/Dec, 2008).A emergência da tecnologia social: revisitando o movimento da tecnologia apropriada como estratégia de desenvolvimento sustentável. A emergência da tecnologia social: revisitando - movimento da tecnologia apropriada como estratégia de desenvolvimento sustentável, 42(6), I069-1094.

ROLLIN, J., Vicent, V. (2007). Acteurs et processus d'innovation sociale au Québec. Québec: Université du Québec.

RTS. (20I I). Mapeadas pela RTS:Tecnologia Social. Retrieved May I2, 20I I, from http://www.rts.org.br/rts/tecnologia-social/apoiadas-pela-rts 
RTS. (s.d.). Tecnologias sociais vencem prêmio ODM. Retrieved May 15, 20II, from http://www.rts.org.br/noticias/ destaque-2/tecnologias-sociais-vencem-premio-odm

RUTKOWSKI, J. (2005). Rede de tecnologias sociais: pode a tecnologia proporcionar desenvolvimento social? In: Lianza, S. \& Addor, F.Tecnologia e desenvolvimento social e solidário. Porto Alegre: UFRGS.

SACHS, I. (2002). Caminhos para o desenvolvimento sustentável. Rio de Janeiro: Garamond.

SACHS, I. (2004). Desenvolvimento includente, sustentável, sustentado. Rio de Janeiro: Garamond.

SILVA, D. R., Sampaio, J. L., Alencar, F.A. (2009). Migração sazonal cearense: via para o trabalho escravo contemporâneo. Anais do Encontro Nacional de Geografia Agrária. São Paulo.

SOUZA, C. (Jul/Dec, 2006). Políticas públicas: uma revisão da literatura. Sociologias, 8(I6), pp. 20-45.

THOMAS, H., Fressoli, M. (2010). En búsqueda de una metodología para investigar tecnologías sociales. In: Dagnino, $R$. P. Tecnologia social: ferramenta para construir outra sociedade. Campinas: Komedi.

WCED. (1987). Our common future. Oxford: Oxford University Press.

YIN, R. K. (200I). Estudo de caso: planejamento e métodos. Porto Alegre: Bookman. 